\title{
Twi Language
}

National Cancer Institute

\section{Source}

National Cancer Institute. Twi Language. NCI Thesaurus. Code C154182.

A dialect of the Niger-Congo Akan language spoken by the Ashanti people in southern and central Ghana. 